-that the Federal government makes each year in basic research in political science.

\section{About the Author}

Herbert A. Simon of Carnegie Mellon University received the APSA's James Madison Award in 1983. He was awarded the Nobel Prize in Economics in 1978.

\title{
The Nature of Contemporary Political Science: A Roundtable Discussion
}

\author{
Kristen Monroe, Gabriel Almond, John Gunnell, Ian Shapiro, \\ George Graham, Benjamin Barber, Kenneth Shepsle, and Joseph Cropsey
}

\section{Kristen Monroe University of California, Irvine}

What is the nature of contemporary political science? What shared concerns bind us together as a discipline, providing a common definition and direction to our intellectual enterprise? These questions were on my mind as I organized the section on formal and normative political theory for the 1989 APSA meetings. Initially, I had wanted to sponsor a panel to address the nature of formal and normative theory. I knew I was a bit uncertain about the precise nature of these fields and sensed that other scholars shared my desire for greater clarity. Then I read Gabriel Almond's "Separate Tables" (PS: Political Science and Politics, 1988). The surprisingly diverse and intense reaction this article generated in the profession suggested the confusion extended beyond my own subfield and into the discipline as a whole. All of this provided the impetus for the round table whose discussion is summarized below.

Since Almond's article argues there is a methodological separateness that limits us as a discipline, I tried to choose panel discussants to reflect the disparate parts of political science. I spoke with each panelist in advance and, drawing on their suggestions, I constructed and circulated a few key questions around which our discussion would be organized. As is obvious in the following remarks, panelists expressed quite different views, but each participant touched on the following questions in some way: Is there a core to contemporary political science? If so, what is it? If not, does its absence matter? Should there be a core? And how important is communication among the different branches of political science?

Each panelist made a brief statement on this topic, focusing on these particular questions. Their remarks are reprinted below, with their per-

\section{Is there a central core to political science? Yes.}

mission, and in the hope that such discussion may foster our common intellectual vitality.

My own thoughts on these questions can be expressed succinctly. Is there a central core to political science? Yes. What is it? For me, it's a little bit like love. I know it. I recognize it when I see it. I respond to it with great excitement and a feeling of being alive. And I'm prepared to follow it wherever it leads me intellectually. But it's still hard to define. For most of my early professional life, I would have said that the central core had something to do with power and influence. After spending the last five years talking to David Easton and Harry Eckstein, I would also now include a consideration of the authoritative allocation of values. (This concept was articulated in another form by Lucian Pye in his 1989 Presidential address.) Finally, my deep and enduring intellectual friendship with Joseph Cropsey prompts me to add a third component for our discipline to consider: the proper and the actual relationship of the individual to the society in which he or she lives.
Does the absence of a central core matter? Can we produce good, competent work by just replicating what we've traditionally done and without the kind of periodic, continual, and even heated discussion and debate over the proper nature of our common enterprise? It's possible that without such periodic intellectual shocks we can produce competent work, but such work will remain rather banal. Is such work what most of us would call good? Probably not.

Finally, is it necessary to talk to each other, to be forced to table-hop, in Almond's metaphor? Yes, I think it is. Some shared vocabulary probably is necessary for the most fruitful exchange. Certainly given the vast amount of literature existing in any subfield in the discipline, specialization is inevitable, if only to produce a common set of concepts in which to converse and disagree. But it is certainly more interesting to talk with people who are different. It gives a vitality and excitement to our work which is otherwise lacking. It forces us to rethink the basic assumptions and preconceptions which drive our individual research. It keeps us intellectually young and makes us alive. And that, I suspect for most of us, is the main reason we do this job.

\section{Gabriel Almond Stanford University}

In my recent sermons to the profession, I have felt a bit like a minister or rabbi of a rich congregation in a prosperous season, reminding his parishioners of their mortality and their spiritual obligations. We have grown enormously, five-fold, during the course of my own professional career. We have acquired powerful skills, proliferated subdisciplines, and have extended our influence all over the world, most significantly in the Communist-MarxistLeninist world. My most striking and moving experience during my 1989 teaching stint in the Soviet Union was my encounters with the members of Chairs in Scientific Communism at the universities in Moscow, Leningrad, and Kiev. With almost no exception, they were quite disenchanted with Marxism-Leninism 
and were turning to empirical

Western-style political science, which they called politology. I carried back with me about a dozen curricula vitae of Soviet colleagues who would like to be retooled in the U.S. It is at this historical moment of the vindication of the Western political science tradition that I want to remind my colleagues of the state of the discipline. If we look inside our departments, we see a loose aggregation of special interests, held together by shared avarice in maintaining or increasing the departmental share of resources: tenure-track billets, salary increases, reductions in teaching loads, liberal leave policies, and the like. And in allocating the resources within departments, typical logrolling and coalition behavior are the order of the day.

The situation I described in my paper, "Separate Tables," makes this kind of departmental policy inevitable. Straussian political theorists share no professional values with their behavioral colleagues. Public choice theorists have come into the discipline largely through lateral immigration from economics. For them, the rest of the political science profession is engaged in doubtful projects, misallocating scarce resources. Critical and Marxist theorists evaluate their positivist brethren according to the religious criteria of sin and error, and they question our very professionalism. Any department in which these schools and sects have taken root cannot decide professional issues on the basis of principle, since they have no principles on which they agree. They can only act jointly on the basis of a common interest in rewards and benefits.

On the logic of it, political theory ought to be the core of the political science discipline. It ought to codify the history of the discipline, the development of central ideas, concepts, and theories. And it ought to codify these concepts all the way up from Plato and Aristotle to Dahl, Converse, and Riker. It ought to face toward the discipline, interact closely with its various parts, and relate them to one another. Political theory hasn't been performing this function in the last decades. Rather, it has, with few exceptions, been traumatized by the diffusion of scien- tific aspirations and methods into political science, and seduced by the simplistic temptations of 1960 s and 1970s thinking.

The idea of political theory as a core subject matter persists in the Ph.D. qualifying examination of some graduate departments, where the history of political theory is the only required subject, either through examination or through course requirements. But it is not a genuine disciplinary core; rather, it is more in the nature of a pro forma tribute to tradition. In the first decades of professional political science in the United States, the substantive focus of the discipline was on governmental institutions and processes. A Ph.D. in political science was assumed to be knowledgable about these institutions and processes-in the descriptive and historical sense, in the real sense, and in the philosophical sense. A Ph.D. in political science and the universities which granted these degrees required the mastery of all the fields of political science: American government and politics, comparative government and

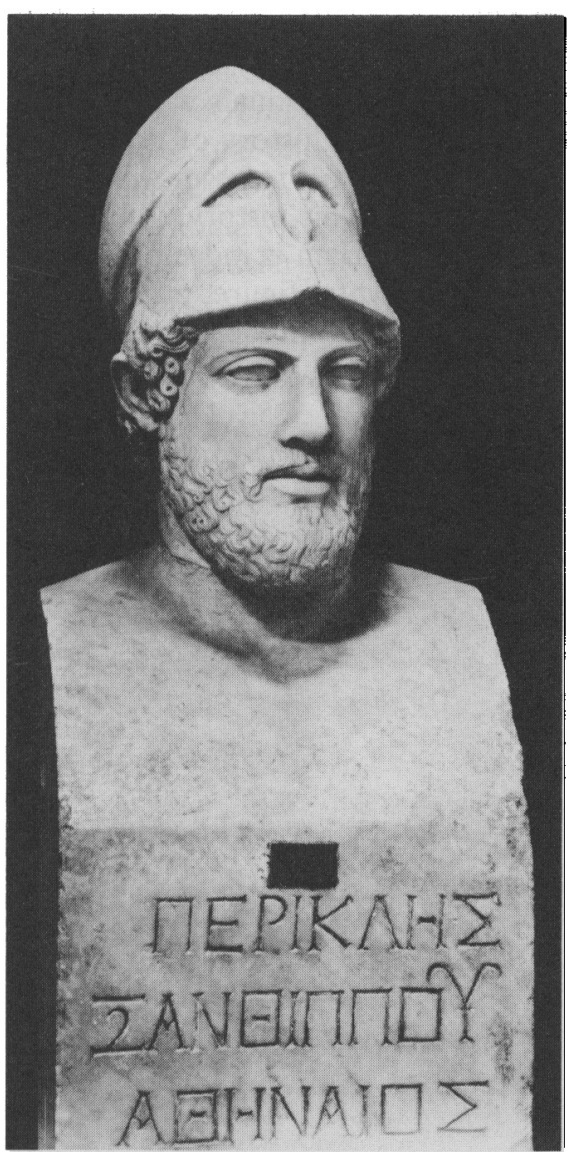

Pericles. Library of Congress. politics, and international organization and politics. He or she was supposed to be able to analyze these institutions in historical, legal, and philosophical terms. While there was specialization, there was still the assumption of mastery of the whole, and this was more than an assumption.

In this early conception of the discipline, the history of political theory was the core subject. One moved from Montesquieu to the Founding Fathers and the Federalist, and from these concepts to comparative political institutions, in the legal and the descriptive sense, and to empirical and normative theory.

That was what was special about the Ph.D. degree. You had to know it all, a part of it better than the rest, but you had to have more than passing familiarity with it all. You could understand the discourse of all of your colleagues, and were able to judge their performance of the students of any political science subject matter, the qualifications of new faculty appointees, and qualifications for promotions in rank, and to tenure. One could speak of the unity of political science in these decades.

Without this professional unity, departments as such cannot make sound decisions on how they ought to grow, which subspecialties to foster, which faculty to reward for performance, how to select our students or evaluate their performance. Inevitably, these decisions get made by the subgroups, the specialists, or the sects, as the case may be. And there is no one to watch over the larger professional interest. I do not speak of the decline of departmental civility, which has its own costs, difficult to measure, but of great importance.

Does it make any sense to speak of the unity of political science today? Is it thinkable that the Straussians can begin to acknowledge professional brotherhood with contemporary empirical political science? Can the public choice people recover the old institutionalism still abundantly around them, before venturing off into a new institutionalism? Can the critical political theorists and the Marxists accept a common obligation to seek scholarly objectivity however difficult that search may be? 
The final question Kristen Monroe put to this Roundtable was, "What issues should concern us as political scientists over the next ten years?" I would hope that this problem of the unity of the discipline, of the relationship among its parts, and of the requirements of its professionalism would be high among those priorities.

\section{John Gunnell SUNY at Albany}

What I take to be the core of professor Almond's argument is that there is at present in political science an uneasy separateness which he has schematized in a four-cell matrix consisting of the soft left (an attack on the mainstream profession and a call to join the political fray), the hard left (socialist and dependency theories), the soft right (Straussians, etc.), and the hard right (formal theory and classical political economic assumptions). Each cell has its own, somewhat self-serving, account of the history of the discipline, but in each case there is a failure to represent history adequately. This in turn distorts what political science is all about, and the real center of the field is obscured by separate and outlying tables.

Almond argues that we must get our professional history straight, and once we give an account of the real history of the discipline, we will see that it does not lead to peripheral and separate tables but to a methodological pluralistic but objectivityaspiring core. This real history, he suggests, is represented in a lineage from Plato and Aristotle, leading through subsequent classics of political thought to Alexander Hamilton, and eventually to Robert Dahl and Seymour Martin Lipset. This, he maintains, is the historically correct version of our disciplinary history -a discipline which has made important contributions to the perennial effort to bring knowledge to bear on the human condition.

I agree with Professor Almond on two counts: we have an uneasy separateness in political science, and to understand it, we must get our disciplinary history straight. But even as a broad sketch, I am unable to accept Professor Almond's image of that past which, I am afraid, is at least as self-serving as accounts emanating from any of the separate tables. Looking for the past of American political science in an ancestry stretching from Aristotle to Max Weber is, indeed, a dubious genealogical project. We can, I suppose, understand why the pantheon of classic political philosophy is a more comfortable image of our roots. Studying the real history of political science is, as Gene Poschman has suggested, something like investigating the origins of sausages and legislation-matters which we might not wish to scrutinize too carefully lest we risk disillusionment. But maybe disillusion is better than delusion.

The real history of American political science requires looking less at truly remote and tangential figures, such as Aristotle, than at the founders of the discipline, such as Francis Lieber and John Burgess. It also means facing the fact that individuals such as Burgess were racists and imperialists, and that many of the others who were most instrumental in shaping the discipline were simply, in themselves, not very interesting.

One of the individuals who belongs to the real history of political science, and who Professor Almond does include in his history, is Charles Merriam. Merriam is indeed an interesting and pivotal figure, and, as recent scholarship indicates, a com-

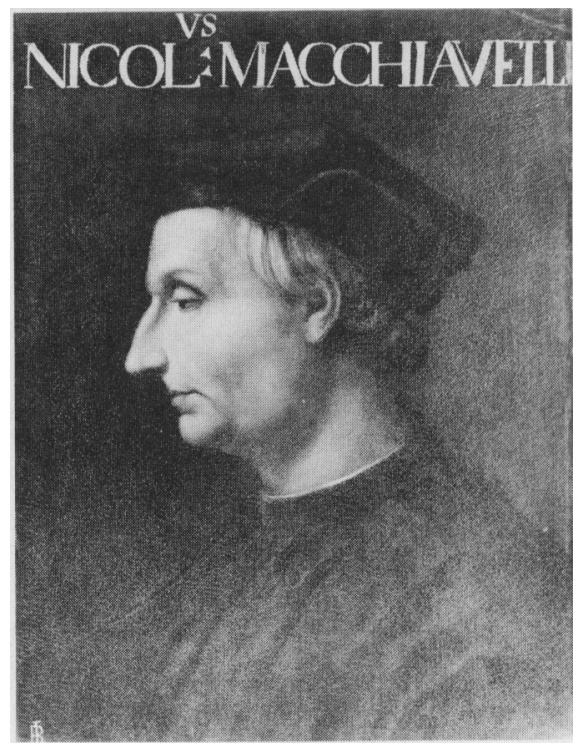

Nicol Macchiavelli. Library of Congress. plex and circumspect person. But in Professor Almond's history, Merriam appears as merely one of the venerable figures who furthered the progress of mainstream political science and the process of bringing knowledge and power into accord. One reason why I am uneasy about Professor Almond's account of the history of political science is that $I$ am working on a book on this subject, and, as part of my research, I have read a number of oral histories, including that of Professor Almond. Part of his discussion of Merriam in this more private history involves an episode in which Merriam required Almond to delete portions of his dissertation dealing with wealth and power in politics, because of potentially embarrassing references to the Rockefellers, who were benefactors of the SSRC and the University of Chicago. I think that this tells us more about the real history of political science than any reference to Aristotle, and it also tells us about the difference between real history and rhetorical history.

The real history of political science would inquire carefully into the relationship between public and academic discourse in the United States and into the relationship between the American university and the structure of political authority. At least in the early years of the discipline, the conversation about this issue significantly structured the field of political science. And from its earliest beginnings in the 19th century, political science was conceived as a practical science. Every major argument about establishing scientific purity and objectivity was primarily an instrumental claim in service of the idea that the authority of knowledge should have a claim on political authority. In the American context, the social sciences, and the university as a whole were not institutionally integrated into the structure of political authority, and as practical sciences, with an end in action, the persistent issue was how to speak truth to power. The internal history of the discipline could easily and accurately be interpreted as the history of successive strategies for closing the gap between public and academic discourse.

Does political science have a core? 
The answer must be no. To some extent, we can explain the lack of such a center by looking at the real history of the discipline. From its birth as a professional association in 1903, political science as a field was more a holding company for some diverse enterprises dealing with the study of politics than a field with a theoretical core, as economics, for example, tended to be. A large part of the history of political science has been involved with a dream of finding a core and establishing a total identity. And Professor Almond's sanguine public history is simply one more chapter in this search for a way to hold the centrifugal forces in check.

Nevertheless, the notion of separate tables suggests something more than a perennial malaise about identity. Political science in recent years has become increasingly dispersed and pluralistic. As divisive as the debate about behavioralism in political science, for example, may have been during the 1950s and 1960s, there was at least an argument that joined the tables to one another. And in the early stages of the postbehavvioral era, with claims such as those of David Easton about a new revolution in political science, the constitutive conversation about the relationship between public and academic discourse was reawakened as a common concern. There is indeed separateness in dispersion today, but it is more than spatial, more than simply a factor of conditions endemic to political science from its origins.

The dispersion today is accentuated by the lack of an animating argument. This loss is in large measure due to the exit of political theory, or much of what constituted this subfield, from intellectual and even institutional involvement in political science. This was in many respects welcomed by both sides who participated in the debate about behavioralism. But the separateness engendered by liberal pure tolerance has divested political science of conflict, let alone agreement. Political theory exited political science less for intellectual reasons than to meet the demands of academic professionalism in the modern university. Its absence has contributed not only to separate

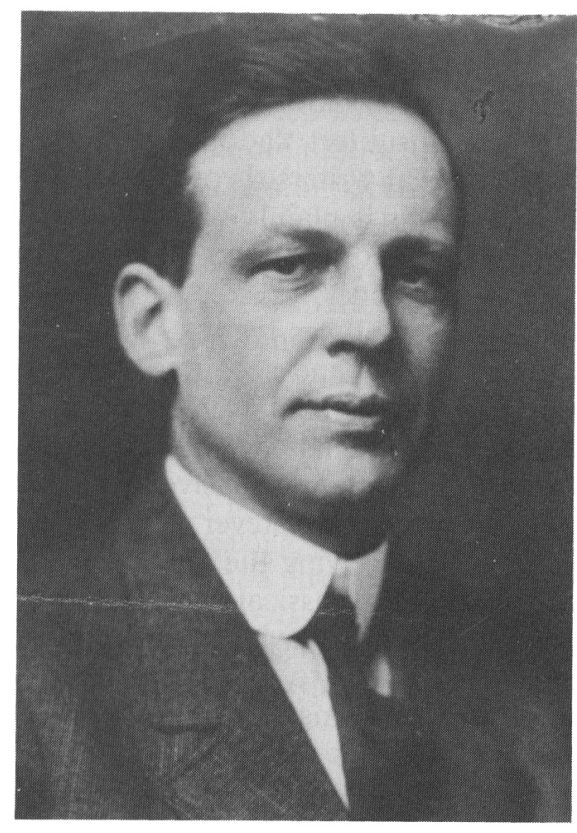

Charles F. Merriam

tables but to separate conversations.

For most of the history of political science, political theory was the basic locus of disciplinary self-consciousness. It was in this literature that questions about the state and identity of political science were posed. It was here that the issue of theory and practice was confronted. With the emigration of political theory to its own intellectual and professional archipelago, from which it makes only occasional visits to its now alien homeland, and largely only as a location for discussing its own internal affairs, political science lost a large measure of its critical self-awareness. And political theory lost its connection to the principal piece of institutional reality that tied it, however indirectly, to politics.

\section{Ian Shapiro Yale University and Center for Advanced Studies in the Behavioral Sciences}

I agree with much of Gabriel Almond's diagnosis, but I think the problem is more serious yet. The belief that an increasingly specialized and fragmented discipline of political science can be unified only by turning to a political theory core assumes that there is such a core. In fact the specialization that has been characteristic of many social sciences over the last few decades has afflicted political theory as well as-perhaps more than-other subdisciplines of political science. Historians of ideas of various partisan stripes, moral theorists in the stamp of John Rawls, game theorists and public choice theorists, anti-theorists who subscribe to a family of related "post-isms," and a variety of others all lay claim to the mantle of political theory. Notable about these groups is that typically they either ignore or polemicize against one another, that they multiply esoteric terminologies, and that whenever possible they travel in packs.

The causes of this fragmentation are various. Like the economic division of labor, once begun it is to a degree self-generating. But this dynamic is reinforced by other factors, both intellectual and institutional. We live in an age when there is no predominant paradigm or set of problems or methods or even preoccupations in the discipline. Partly for this reason the impetus to focus on small and sharply delineated problems remains powerful, even if it makes considerably less sense than it would were there a widely agreedupon intellectual agenda. The lack of such an agreed upon agenda obviates the felt need to explain or justify the broader relevance of one's work. Indeed, in such circumstances interdisciplinary ambition almost inevitably seems risky and grandiose. The more prudent path less fraught with the possibility of quixotic failure is toward smaller problems or parts of problems, and it cannot be surprising that many people opt for it. For the intellectual sources of fragmentation are underpinned by institutional ones. The organization of political science departments is confederal, as Brian Barry has noted, and soinevitably-is the structure of incentives for survival and advancement. Search committees and promotions decisions generally operate within subfields, at least as a decisive first hurdle, and as a result the "rational" strategy for young scholars is to shape their thinking and research to fit within the existing confederal structure. ${ }^{1}$ The intellectual division of labor within and among subfields 
of political science seems here to stay, and political theory is not special in this respect.

A second reason why political theory is not likely to supply the remedy Almond seeks is a byproduct of the first. If empirical political scientists show little interest in the concerns of political theorists, a large part of the blame lies with the theorists themselves for showing so little interest in politics. Useful as the infiltration of moral philosophy and the methods of microeconomics into political theory in the past two decades have been in some respects, their internal complexity, preoccupation with counterfactual analysis, and relative disregard for problems of implementation have fueled an already prevalent tendency among political theorists to write primarily for one another. Much too much political theory, I have argued elsewhere, feeds exclusively off its own controversies via the mutual opposition to one another of gross concepts -misleading abstractions that can appear plausible only when attention is fixed on the evident defects of an opposing misleading abstraction. ${ }^{2}$ The major theorists of the tradition did not behave in this way. Plato, Aristotle, Augustine, Hobbes, Locke, Rousseau, Marx, Mill, Tocqueville, and Dewey all took holistic and interdisciplinary (to the extent that they were aware of what we think of as disciplines) views of politics and society; they worked their theoretical arguments through the problems and conflicts of their times, they grappled with issues of evidence and causal argument, and they thereby assumed the responsibility to make their arguments pertinent to the concerns of others. In contrast, many of today's political theorists seem most bent on dividing up and squabbling over the terrains of ideal theory and textual exegesis; as a result they have only themselves to blame if no one else is interested in what they have to say. ${ }^{3}$ In a rare but revealing moment Rawls $(1971,51)$ concedes that theorizing about justice cannot be "founded solely on truths of logic and definition" on the grounds that "the analysis of moral concepts and the a priori is too slender a basis." Yet from this he draws the inference that "moral philosophy must be free to use contingent assumptions and general facts as it pleases," asserting that this assumption informed the view of the subject "adopted by most classical writers through Sidgwick." Rawls is plainly wrong here. Much of the political and moral theory of Hobbes, Locke, Bentham, Marx, and Mill was really philosophical psychology and accounts of the causal dynamics of power, and their political arguments depended for their force on the persuasiveness of those accounts. Whatever the difficulties of conceiving the task of the theorist in this classical way (and they are many), Rawls fails to appreciate that refusal to do so is bound to be self-defeating. In his own case he simply asserts that his assump-

\section{If we look inside our} departments, we see a loose aggregation of special interests, held together by shared avarice in maintaining or increasing the departmental share of

\section{resources.}

tions about these matters are uncontroversial and widely shared when it is easily shown that they are not $(1971,12,131,137) .{ }^{4}$ The result is that methods like Rawls's tend to turn political theory into preaching to the converted; at best they confirm the prejudices of those who agreed with their controversial assumptions in advance while reinforcing the opposition of those who do not. At worst-and often in fact - they generate internal preoccupations with the small nuances of self-generating debates that none except initiates have the time or the interest to disentangle.

What to do differently in these circumstances of advanced and selfreplicating division of labor in political science and political theory alike? The injunction I would offer is that instead of worrying about how much we should be talking to one another we should be worrying more about talking directly about politics than we characteristically do. It is not my claim that the various esoteric methods that students of politics have found helpful should be abandoned, but these devices should be linked more often and explicitly to actual problems in a commonsense idiom. This would militate against the powerful tendencies in all of our subfields toward method-driven rather than problem-driven analyses, which is undesirable in its own right and fuels the intellectual division of labor from yet another direction. Put in the terms of Almond's metaphor, we should worry less about where we sit in the cafeteria, how many tables there are, how they are arranged, and who sits where and talks to whom, and worry more about what is going on outside and about how what we have to say about it can be made intelligible to these who are living the reality of what we take politics to be.

Following this course of action would not necessarily produce a more unified discipline, but it matters to get clear on why this is so. What we disagree about most basically is not what political science is or should be. That disagreement is a mere symptom of what really divides us, namely competing conceptions of what politics is and what it should be. Given this fact, it is inevitable that there will be a degree of contention among students of politics about both method and object of study, and a comparatively eclectic discipline of political science as a result. But if we all aim our critical capacities more directly at what we take the reality of politics to be and assume the obligation to explain its significance to the uninitiated in nonesoteric terms, at least we might have some confidence that our disagreements will be about something real rather than about artifacts of our own intellectual processes. Some will find my skepticism about the possibilities for a more unified discipline difficult to accept. To them I would nonetheless offer the same injunction, because if there is ever to be a more unified discipline of political science it must surely find its foundation in a measure of agreement on 
what politics is and what it might in principle become.

\section{George Graham Vanderbilt University}

The relation between separate tables and the "Cafeteria of the center" that Almond refers to brings to mind the quality of food one expects from a cafeteria. The separate table is better designed for the leisurely extensive discussion of particulars. One may not achieve detail of comprehension of flavors or nuance, as one rattles through the cafeteria line. The major need is not for unseasoned meals, for bland flavors, acceptable to anyone as a compromise. What we must focus on here is a means of comprehending what it is that is so important to the various chefs and what it is that they are creating. One does not learn this from a cafeteria meal. Food for thought need not be bland.

The problem is not one of diversity or variety per se within the profession. The problem is one of the intensity of the commitments to the particular approach-to the comprehension of politics-one advocates. The intensity comes from those who are most active within the profession, most interested in exploring new advancements in political understanding. Interestingly enough, in the context of Almond's selection of dining metaphors, the first words of the classic discussion of the intensity problem in democratic theory are "Dinner is over" (Kendal and Carey, APSR, March, 1968: 5-24). The problem of intensity and its resolution is exemplified by conversation after dinner which entails the introduction of reasons for preferences. The task in terms of democratic theory parallels dealing with the intensity of feelings over approaches within the profession. There must be institutional resolutions to the problem, the problem being learning how to converse between the tables so that we can go beyond mere majority rule of control within the discipline. Discourse and deliberation are necessary. The framework for appropriate discourse within the profession requires that individuals, together, attempt to comprehend what it is that is so interesting to others. I do not find this in most of the discussions that have been in print so far about the separate tables. Instead of writing off as less important what is different, one must try to comprehend why a certain way of studying the political is fascinating to another person. One is reminded of Michael Oakeshott:

It is with conversation as with gambling, its significance lies neither in winning nor in losing, but in wagering. Properly speaking, it is impossible in the absence of a diversity of voices: in it different universes of discourse meet, acknowledge each other and enjoy an oblique relationship which neither requires nor forecasts their being assimilated to one another. ... final measure of intellectual achieve-

\section{Looking for the past of American political science in an ancestry stretching from Aristotle to Max Weber is, indeed, a dubious genealogical project.}

ment is in terms of its contribution to the conversation in which all universes of discourse meet. (Oakeshott, 1962, 198-199)

Oakeshott is describing a process that most of us recall as the most exciting part of graduate school, the time when talking with other people about what they were doing and learning was our primary and shared concern.

In speaking of conversation, I wish to emphasize the setting of quietness, of friendly and common interest in the activity. A multiplicity of paradigms exists, and standards may emerge from intellectual conflict. Debate is in one sense true but potentially in another sense false because the conflict cannot be treated as parochial.

The problem within the profession is a problem of intensity. It's a problem of personality conflict. If we can overcome those kinds of conflicts and can find ways to develop the deliberative processes, then we'll make some advances towards having different people learn what different schools are trying to accomplish in the process. The history of political science can be written in many ways. But the history has constantly gone back to the problem of our substance - politics-defining what is the core. And the core has essentially focused on questions and problems that emerge from a study of government and governmental processes. The key is to focus on these issues so that we allow the different kinds of questions that people want to pursue to guide which sort of theory is used to define the problems. If one focuses on the substance or nature of political science, one can then start looking at the differences and the conflicts differently; that is, as means to answer different kinds of questions. We must explore how different schools of theory contribute to answering different important questions about politics as we enter this postparadigm era of the discipline.

One of the most important points that can come out of such discussions is a reflection on the institutional consequences, especially in the case of graduate education. Not many people on this panel probably will change their view of politics very much in the next 25 years. But current graduate students tend to learn. They want to know more than we know. They are willing to look at more than one approach before we tell them, if we employ our own appropriate rhetorics, that there is only one approach. It's the diversity of the various tables from which they can learn different theoretical approaches, different language games, that (in the graduate students' minds) will develop the kind of energy to go beyond all of us with our particular limiting commitments at this particular time.

An obvious point is that much tension is institutionally caused. Universities have limited positions for our friends. It is also true that there are limited resources within the profession. Often, our intellectual battles come from the self-doubt of people pursuing their own perspective and legitimating their perspective rather than from an intellectual commitment to uncover better truth about politics. If you trace through some 
battles raised by the various schools within political philosophy, or the profession as a whole, you often hear, buried in the second and third paragraph, a concern about various ways of defining faculty positions for advertisements, whether or not certain journals will accept certain kinds of articles, and so forth. It is unfortunate that we as political scientists are often driven by such human concerns. The university structures and rewards seem to be set up so they intensify the conflict over these approaches more than is necessary. If instead of seeing our situation as a "resource struggle" we took the time to try to learn what other people are doing within their models, we would not be limited to seeing politics only as seen through our own separate jargons.

\section{Benjamin Barber Rutgers University}

The central question for political science as a discipline concerns not the nature of our discipline's "core" but how and why it continues to reflect the inequalities and disparities of power and influence found in the society we affect objectively to study.

If we look at the larger society rather than our own little society, it seems apparent that we are at once affected by its inequities without being moved to examine them critically. Why are there so few blacks, so few women, in the political science discussions we conduct on the themes of race or gender? Look around this room, and ask yourselves whether our subject matter is really as white and male as we are?

Perhaps the question we need to ask is whether we are a discipline or a club? Are the boundaries that matter those that divide us from within into subspecialties that have difficulty communicating? Or those that demarcate our conversation from the conversation of outsiders? We may have difficulty talking to one another, but we are all participants of equal standing in the conversation. What of those excluded from it altogether? They are without voices, and are thus disempowered in a subthe but consequential fashion. Their intellectual powerlessness in the con- versations of the club mirrors the social and economic powerlessness of the groups they represent.

Recently, Americans, and especially, American political scientists have been celebrating, even reveling in, the demise of communist systems - as if their breakdown were somehow a proof of our virtues, their weaknesses testimony to our strengths. Yet America is afflicted with its own problems and is closed in ways, though less visible, that are debilitating in their own way. The closed societies of the East seek liberty on the Western model, admiring the efficiency and liberty of the open society. Yet our societies are open only with respect to those already admitted to the conversation. You have to be in the club to appreciate and utilize its discourse. Open to

\section{Does political science have \\ a core? The answer must}

\section{be no.}

many, it remains closed to some, not simply because they are "disadvantaged" or "oppressed" but because, more damagingly, they are rendered silent. Silence is the most toxic form of powerlessness.

Comparatively speaking, we are freer than most societies; but this only suggests how misleading comparison across normative values such as liberty and participation can be. America is an open but not a completely open society. Political science is an open, but scarcely a totally open profession. Its chief problem is neither jargon nor "separate tables" but its inability to achieve genuine inclusiveness; the impermeability of its membranes. Inasmuch as it remains a club-however inadvertently -its potential as a liberating conversation of everyone in society about the nature of that society will remain curtailed.

This is not just a theoretical objection. Take a walk around Atlanta at night, and you will experience the limits of the open society. I do not just mean for us-because of the fear of crime in the streets. I mean for those who live in Atlanta, in its less advantaged neighborhoods, those pushed aside to make room for the sterile metropolis that is the new downtown, those whose problems remain on the periphery of mainstream political science.

Political science does in fact have a core: it is called politics. But politics must be defined by what occurs in the streets, not what we can conveniently observe or systematize as data in the laboratory. Alfred Cobban quipped over thirty-five years ago that political science was mostly a device for avoiding science without achieving politics. We have overcome the behavioral pretensions of the Sixties when some insisted the self-conscious study of human institutions and the consciousness that produced them could be studied in the same way we studied molecular physics. Scientism is dead in social science.

But the tendency to exclude the genuinely political from the study of political science-because it is so often messy, ambiguous, controversial, and in tension with standard paradigms-continues. I am suggesting that this may in part be a consequence of the clubbiness of our conversation, our inability to hear or give voice to those who have the most to teach us, who have been shut out of our conversation-or marginalized in it by the establishment of academic slums and backwaters with names like Afro-American studies, or women's studies. Above all, what our discipline does not need is complacency. For complacency is the enemy of freedom and democracy, and those who study what they aspire to be, rather than what they are, quickly are transformed from political scientists into ideologists. And, much in the same way, those who celebrate their liberty rather than practice it are the first to lose it.

\section{Kenneth Shepsle Harvard University}

As the only hard-core rational choice theorist on the panel, the reasons for my presence here should be obvious. I shall try not to dis- 
appoint, though in qualification let me note that the portrait I paint in these next few minutes employs, mostly for dramatic effect, more broad-brushed rather than pointillistic technique.

The question posed to us by chairperson Kristen Monroe is whether or not there is a core to contemporary political science and whether there should be one. My brief answers are no and yes, respectively. Let me elaborate.

Is there a core in contemporary political science? When I first read Professor Almond's PS piece on "Separate Tables," I resonated to its various themes. To paraphrase its conclusion, though giving it my own emphasis, there are pockets of discipline within the profession. But for the most part, the discipline is undisciplined.

The pockets of discipline are selfcontained communities-islands or keys off the mainland is the metaphor I would use. Closed intellectual economies, if you will, is Almond's view. Intellectual trucking, bartering and exchanging takes place within the community's boundaries. For island intellectuals, off-islanders are either hostile tribes, located on other islands, or the great unwashed, located on the mainland. There are attempts to export ideas, but rarely any effort to import them. Exporting takes the occasional form of conquest (other islands), but more often takes the shape of conversion (mainland). Island economies are protectionist, establishing various barriers and other restraints on imports.

The mainlanders, on the other hand, are blithely indifferent to, if not ignorant of, the internecine quarrels, both among and within the various islands off their shores. They are mildly amused by the numerous attempts at converting them. They are content to sample the spices and other exotica exported from the island intellectual economies. On the whole, life goes on on the mainland, changing slowly but mostly staying the same. Mainlanders are content in their undisciplines. They share no common church; indeed, many don't go to church at all.

This is a highly-stylized version of the Almond view. I don't have many quarrels with it, but let me make some observations. In principle, intellectual communities that import ideas, but don't export any, are selfindulgent. This is the problem faced by the mainland in my parable. Undiscipline risks degenerating further into sloth and other vices that sap its productivity. Those that export, but bar imports, ultimately lose vitality once their natural resources are depleted. Those that neither import nor export ideas-a colleague of mine suggests that developmental economics is such a field-are quickly ignored in the world intellectual economy. Some are more self-sufficient than others, but none counts for much in the broader world.

But there is a fourth alternative,

\section{If [we] don't ask [ourselves] how do we... fit into the large world in which humanity is planted ... there is something missing [in our discourse].}

one that allows both mainland and island intellectual economies to survive and even prosper, namely international intellectual trade. And here is where I think Professor Almond goes astray. Causeways and bridges, taking traffic in both directions, are possible. Some, like myself, feel quite comfortable in hailing from a specific island, yet in traveling regularly to the mainland, sometimes to peddle my wares; other times, to sample mainland delicacies. I also occasionally island-hop. One does not have to be a complete Panglossian to come to a more sanguine conclusion about the state of the profession than Professor Almond does. The mainland draws sustenance from the islands, whether behavioral, rational choice, Straussian, Marxist, or statistical. The islands prosper at their respective tasks from having frequent intercourse with the mainland. As in so many other areas of life, specialization need not entail isolation, suspicion, or antipathy. Trade and exchange make us all richer.
To this first question, then, I do not think there is a core in contemporary political science. Rather, there is an intellectual economy. But I do not take a particularly dim view of this to the extent that trade takes place. I think Professor Almond dismisses this possibility too readily.

While I cannot speak with authority about many island intellectual economies, I do believe that the rational choice group in political science and economics have become, after some false starts and selfindulgence, fine practitioners of the art of international intellectual exchange. While some of our tribe are still Teutonic axiom-theoremproof types, most rational choice modelers do American politics, international politics, political theory, and, increasingly, comparative politics. We are as frequently on the mainland as back home. We are interested in legislative structure and process, international regimes, theories of justice, and electoral systems. One should not mistake rigor, consistency, and an intellectually selfconscious point of view for isolation, or rigidity, or even religion. In my particular field of legislative politics, for instance, my own work has been enriched for having been a graduate student peer of Fiorina, Rohde, and Sinclair; a student of Fenno; a colleague of Salisbury; a friend of Jones, Ornstein, Patterson, and Polsby. And legislative studies, in turn, has been enriched by rational choice approaches. It has become conventional to think of legislators maximizing electoral prospects, of leaders of forming coalitions, of structure and procedure inducing equilibria. It is precisely its rigor, its cumulativeness, its coherence that has allowed the rational choice approach the influence it currently enjoys. In sum, intellectual trucking and bartering, entailing lowered trade barriers, promotes rather than discourages a science of politics.

Should there be a core in contemporary political science? The absence of a core in political science is partly an historical accident. Although Almond quite correctly points out that numerous methodological and theoretical advances had their origins in 19th and early 20th century Europe, the fact of the matter is that 
technical developments are not only mostly an American affair, but also are an American politics affair. We are thus stuck in a perplexing dilemma in which many of our most scientific tools, techniques, and theories have been fashioned to understand a single, quite possibly exceptional, political system. This is unfortunate and certainly no basis for elaborating a foundation for the study of politics. In order to do so, and I think doing so would be a good thing, I think we need to restructure our traditional fields. A foundation should, in my view, rest on two pillars: political theory and comparative politics. The first should focus on static principles of individuals, groups, and institutions. They may be positive, normative, or empirical; it is of no matter to me. They are theorems about equilibrium tendencies, discourses on equilibrium desideratum, or statistical forecasts of equilibrium practices. The second pillar is expressly comparative, something all too rare in contemporary comparative politics. Its focus is change, perturbation of equilibria, comparative statics and dynamics. It, too, may take either a positive, normative, or empirical turn. It seeks to determine what will or what should or what actually does happen when relevant parameters-history, culture, institutional practice, economic condition-change. It is an analytical, not a geographical, comparative politics.

I obviously do not have the time to develop my view further. To sum up, there is currently no core or discipline to political science, though there are some pockets of discipline. Exchange among intellectual communities has allowed for some vitality, some growth, and some muddling through. I wish there were a core, a foundation, and I cannot imagine one without the rational choice school playing a significant role. Adam Smith, to the contrary notwithstanding, rarely can single individuals effect the restructuring I believe would facilitate this development. I am encouraged by the pace with which more traditional political science undertakings have incorporated the rigor and coherence, if not always the substance, of rational choice. When we reassemble in 25 years-I am sure we are all prepared to wait-I expect that rational choice will still be with us, though distinctly less American, distinctly more comparative.

\section{Joseph Cropsey University of Chicago}

There are certain advantages to speaking last. Everything's been said ... almost. In a previous incarnation, I used to run around a lot with economists and there was a question that was raised among economists

\section{If empirical political}

scientists show little

interest in the concerns of political theorists, a large part of the blame lies with the theorists themselves for showing so little interest in politics.

that led to an answer that comes back to me now. They used to ask themselves "what is economics?" I forget who it was-I think it might have been Dennis Robertson-who said economics is what economists do. At the time, that struck me as a rather inane answer to a question that betokens some lack of reflection on the chief subject, which is "what is it that they're doing and what are they?'" Now I am myself in the position of the person described by Mark Twain, who said that when he was at a certain early age, he thought his father was really very supid. But the older he got, the more his father seemed to have learned. And it now seems to me that the economists who gave the above-described answer to that self-reflective question were not all that wrong. Whatever wisdom there is in their answer might just possibly be relevant to the question that we're asking now, which really amounts to "what are we doing?" What is a political scientist and what is political science? Now, if some- body were to suggest that political science is what political scientists do, I think he might capture the spirit of much of what's been said today.

I have thought a little bit about this question over a long period of time. If one were to propose that political science is what political scientists do, you would in a way already have given an answer, an implicit answer, to the question: Is there such a thing as political science, which is a conversion of the question: Is there a core? I take it that there is such a thing as political science. I take it that it can be distinguished from nursing education, archaeology, and lots of other subjects that appear in university catalogues. Going back a long way, which is a bad habit of mine, I am thinking of a certain passage in the Platonic dialogue Theaetetus. I'm reminded that if you can give something a name and have somebody else understand what you're talking about when you pronounce that name, then there must be something here which is being named. Now, how far can you get with this sort of irenic approach to the question: Is there something that we are in fact talking about when we pronounce the name of our discipline? We're struck, and rightly struck, by the diversity. Every department, every decent department, will reflect the diversity that exists in the minds of serious people who put their thought to the question: What about politics? Well, there are a lot of different ways of approaching that question and it's a good thing that there are that many different ways. I would say that the political science department copies the paradigm of the university. There would not be a lot of departments in a university if any one department had the truth. There wouldn't be a lot of different approaches to political science if there were not a lot to be said for the different ways in which political scientists approach their questions. Now, if we are sometimes struck by the fact that there is tension and there is intensity and there is even sometimes-I regret to say-hostility among the votaries and partisans of this and that, I think that we're being impressed by something that simply has to be there. If it were not 
there, I think it would be a sign that people don't take themselves very seriously. Now, this is not an argument in favor of people being uncivil to each other or disrespectful of the merit of the things that others do. Obviously, in principle nobody is in favor of that. So it appears as if once again we're compelled to be reminded of a piece of wisdom that's probably something like 2,800 years old. It's a little embarrassing to rediscover something that's been around for 2,800 years but it's better late than never.

There were people a very long time ago who said that all is strife. You can read the fragments of the preSocratics and find this said. And then somebody else will say all is love. Well, there is a centripetality and centrifugality, or whatever the right word is, in the affairs of men in the cosmos. That seems to be of the nature of things. More impressive than the fact that there is a drifting apart and a coming together is the fact that the drifting apart and coming together coexist at the same time, that there is a tendency for us to move apart and also for us to coalesce. There is something, and I don't know what it is, that causes that tendency to drift and to coalesce, the two of them to live together. This is a paradigm, if you like, but it is indicated to us not only by the affairs of men but by the constitution of the cosmos. It's a very old piece of wisdom generated by people who faced the same problem that we're now addressing on our very modest scale.

This leads me to a conclusion of a sort. If it could be said with any degree of plausibility that the things that occur to us now, when we address our questions, generally resemble in important respects the things that seem to have occurred to people of thousands of years back, then it looks as if there's something permanent in the affairs of human beings. There's something that won't go away, and something that persists as a question and also that persists as an answer. I would suggest that if we were to look for a core to political science, it would have the character of a relatively small number of questions that will not go away. They have not gone away and I dare say they will not go away. It takes a great deal of audacity to propose one of these questions to you. Not everybody here has to be committed to political theory, and certainly not everybody has to be committed to the history of political theory. There are some good reasons for being

\section{. . . instead of worrying about how much we should be talking to one another we should be worrying more about talking directly about politics than we characteristically do.}

dubious about that enterprise. It's where I've spent my life but I understand that. Nevertheless, I would be so bold as to put forward a question, not the only question, but I think it's a question which if political scientists $d o n$ ' $t$ address, they are indicating that our discipline has undergone a certain impoverishment. I don't know whether to say I blush or I tremble or what but at any rate I hesitate to put this question to you. But I'm going to do it. I would say that if political scientists or social scientists don't ask themselves how human beings fit into the larger context of existence, if they don't ask themselves how do we somehow or other fit into the large world in which humanity is planted, I think there is something missing. I don't say this is the only question. I don't want to say it's the most important question. But $I$ think it is an indispensable question. It's a question that men in all ages have raised, and to the best of their ability. It comes down to us not only in science and not only in philosophy but it comes down to us through scripture and probably other religion. It is the universal question. I leave it with you as a question that should be raised, around which a core may develop. Maybe not. But at any rate, without this question I suggest to you our discipline is somehow impoverished.

\section{Notes}

1. See Brian Barry, "Do Neighbors Make Good Fences? Political Theory and the Territorial Imperative," Political Theory, Vol. 9, No. 3 (August 1981), pp. 293-301.

2. See my "Gross Concepts in Political Argument,"' Political Theory, Vol. 17, No. 1 (February 1989), pp. 51-76.

3 . As one of my colleagues remarked with justifiable chagrin on laboring through an extended theoretical discourse on the difference between equality of opportunity and equality of advantage as principles of distributive justice that revealed not the slightest interest in how either could be implemented even in principle, "this stuff is three points to the right of the decimal!"

4. For an extended discussion of the role of empirical assumptions in political theory, see my The Evolution of Rights in Liberal Theory (Cambridge University Press, 1986), pp. 208-10, 217-18, 230-32, 238, 281-82 and 295-97).

\section{References}

Oakeshott, Michael. 1962. Rationalism in Politics and Other Essays. New York: Basic Books.

Rawls, John. 1971. A Theory of Justice. Cambridge: Harvard University Press. 